\title{
インダクタンス素子を用いた圧電型振動ジャイロの高感度化
}

\author{
正員 菅 原 澄 太石巻尃修大) \\ 非会䝿工 藤 すばる (石巻尃修大)
}

\section{Realization of High Sensitivity in Piezoelectric Vibratory Gyroscopes by an Inductance Element}

Sumio Sugawara, Member, Subaru Kudo, Non-member (Ishinomaki Senshu University)

Under the condition that the two resonant frequencies of driving and detecting modes are different, the sensitivity of a piezoelectric vibratory gyroscope decreases remarkably. In this paper, a method to avoid a decrease of the sensitivity is proposed, and the results on the equivalent circuit consideration and the experimental inspection are also shown. The method is realized by connecting an inductance element to the detecting side in parallel. The vibratory gyroscope has the high and constant sensitivity within a designed frequency bandwidth because a band-pass filter circuit is formed by this connection. As the resonant frequency of the driving side can be freely set in the bandwidth as a result, degrees of freedom for the vibratory gyroscope design increase fairly. The bandwidth on the frequency response characteristic also becomes wide. The validity of such the method that realizes the high sensitivity was confirmed experimentally.

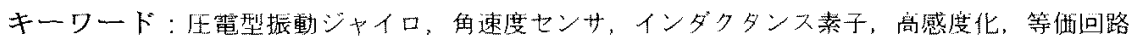

\section{1、まえがき}

压電型振動ジャイロスコープ（以下，振動ジャイロと略） は, カメラの画振れ防止やカーナビダーション・システム などの角速度センサとして実用化されるようになった(1)。 また，最近では車㒳の姿勢制御用としても注目されている。

このような振動ジャイロを構成する場合，要求される周 波数応答特性に応じて駆動側と検出側の共振周波数差を設 定する必要がある。この場合，周波数差老大きく設定する と感度が著しく低下してしまう。これに効して，周波数差 を小さくすると感度は大きくなるものの周波数応答特性が 狭くなり，さらに両振動そードの機械的結合により大きな 漏れ出力が発生するという問題があった。このため，駆動 側と検出側の共振周波数を離して設定した状態で，高感度 化を図る何らかの手法の考案が旺まれていた。

本論文は，このような間題を解決する一方法として，振 動ジャイロの橫出側にインダクタンスを並列に付加すると いうきわめて簡便な方法を提案し，振動ジャイロの駆動側 及び検出側の共振周波数をかなり離して設定した状態でも， 設計したある雕波数带域にわたって感度が大きく一定とな ることを明らかにしたものである。初めに，振動ジャイロ
の入出力電压比之駆動側共振周波数の関係等価回路考察 し(2) (4)，インダクタンス付加時の振動ジャイロの特性を明 らかにする。次いで，その実験的検証結果について述べ(5)， 高感度振動ジャイロが構成できることを明らかにする。

\section{2. 構造と等価回路}

\section{$<2 \cdot 1>$ 構造}

本考案は各種の振動ジャイロに適用できるものであるが， こニでは一例として図 1 (a)のような構造を取り上げる。本 構造は恒弹性金属音片の横振動第一次モードを利用するも ので，纴電セラミックスを接着してその駆動・検出を行う 基本的な爀成である。この動作原理を略述寸ると，まず同 図(b)の上うにx軸方向に第一次モードで振動させた状態で 図示のようにz軸の回りに角速度 $\Omega_{0}$ を印加すると，発生し たコリオリカによって直交したy 軸方向に同図のような同 一周波数の振動が新たに淤振される。この振動の振幅が印 加された角速度 $\Omega_{0}$ に比例する当ので, 本構成は角速度センサ となる。

$<2 \cdot 2>$ 等侕回路

图2は图10振動ジャイロの出力端子に亚列にインダク 


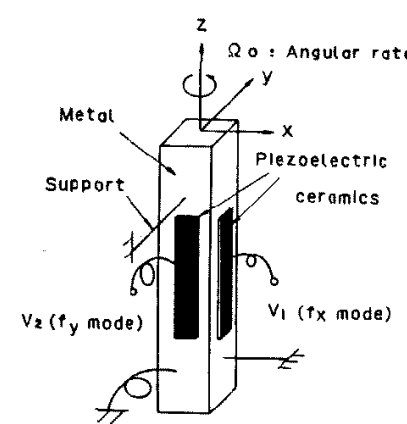

(a)

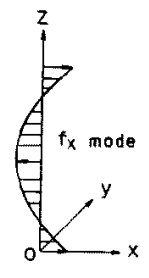

(b)
図 1 圧電型振動ジャイロの構成

Fig.1 Construction of a piezoelectric vibratory gyro.

タンス Ld2 を付加した場合の等価回路である。同図(a)で, $\mathrm{z}_{\mathrm{i}}=\mathrm{r}_{\mathrm{i}}+\mathrm{j} \omega \mathrm{m}_{\mathrm{i}}+\mathrm{si} / \mathrm{j} \omega(\mathrm{i}=\mathrm{x}, \mathrm{y})$ は $\mathrm{i}$ 軸方向の振動 モードに対する等価機械インピーダンスであり， $\mathrm{r}_{\mathrm{i}}, \mathrm{m}_{\mathrm{i}}$, siはそれぞれ等価機械抵抗，等価質量，等価スチフネスで ある。また， $\mathrm{C}_{\mathrm{dj}}\left(\mathrm{j}=1 ， 2 ）\right.$ は制動容量， $\mathrm{A}_{\mathrm{ji}}$ は力係数， $\mathrm{R}_{2}$ は負荷抵抗である。さらに，高 り(6)，F G はコリオリ力である。この等価電気機械回路は, 同図(b)のような等価電気回路に変換される。ここに， $\mathrm{R}_{\mathrm{i}}$ $=\mathrm{ri} / \mathrm{A}_{\mathrm{ji}}{ }^{2}, \mathrm{~L}_{\mathrm{i}}=\mathrm{m}_{\mathrm{i}} / \mathrm{A}_{\mathrm{ji}}{ }^{2}, \mathrm{C}_{\mathrm{i}}=\mathrm{A}_{\mathrm{ji}}{ }^{2} / \mathrm{s}_{\mathrm{i}}, \overline{\mathrm{G}}_{\mathrm{i}}=\overline{\mathrm{G}_{\mathrm{i}}} /\left(\mathrm{A}_{\mathbf{1 x}}\right.$ $\mathrm{A}_{2 \mathrm{y}}$ )なる関倸がある。なお，これらの等価回路では振動ジ ヤイロに与える付加インダクタンスの影響を浮き崕りする ため, 不要な力保数成分, 機械的結合, 入出力閒静電結合 容量などによる影響(7)は全て無いものとして表示されてい 万。

表 1 は，以下の等価回路解析で使用される試作振動ジや イロの等価回路定数の奏測值の一例である。

\section{表 1 夷测等価回路定数の一例}

Table 1. Measured values of equivalent circuit constants.

\begin{tabular}{|c|c|c|c|}
\hline \multicolumn{2}{|c|}{$f_{x}$ mode } & \multicolumn{2}{|c|}{$f_{y}$ mode } \\
\hline $\mathrm{f}_{\mathrm{x}} \quad(\mathrm{Hz})$ & 4864.1 & $f_{\text {fy }} \quad(\mathrm{Hz})$ & 4746.6 \\
\hline $\mathrm{L}_{\mathrm{x}} \quad(\mathrm{H})$ & 105.58 & $L_{y} \quad(\mathrm{H})$ & 97.68 \\
\hline $\mathrm{C}_{\mathrm{x}} \quad(\mathrm{pF})$ & 10.14 & $\mathrm{C}_{y} \quad(\mathrm{pF})$ & 11.51 \\
\hline$R_{*} \quad(\Omega)$ & 6453 & $\mathrm{R}_{y} \quad(\Omega)$ & 5827 \\
\hline$C_{\| !}(p F)$ & 2944 & $C_{d z}(\mathrm{pF})$ & 2930 \\
\hline$Q_{\text {. }}$ & 500 & $Q_{y} \quad ;$ & 500 \\
\hline$\gamma_{\mathrm{x}}$ & 290 & $y_{y}$ & 255 \\
\hline $\mathrm{A}_{1 \times}(\mathrm{gr} / \mathrm{H})^{1 / 2}$ & 0.176 & $\mathrm{~A} z_{y}(\mathrm{gr} / \mathrm{H})^{1 / 2}$ & 0.188 \\
\hline
\end{tabular}

\section{3.インダクタンス付加時の設計}

\section{$<3 \cdot 1>$ 設計の基礎}

この場合，振動ジャイロの検出側の等価回路は定 $\mathrm{K}$ 型の フィルタと見なせるから，損失を無視するとその等洒回路 は図3(a)のように，またこれにさらに終端抵抗と電源をも 考虑したものは同図(b)のよに表される。このようなフィ ルタ回路における諸関倸式から，付加インダクタンス $\mathrm{Ld} 2$
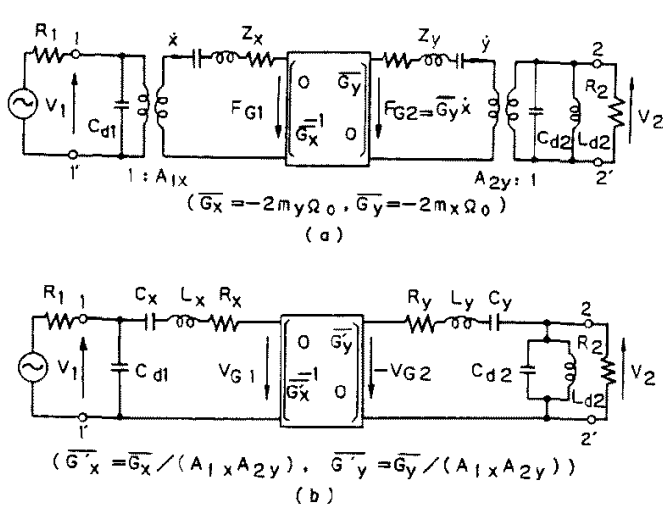

図 2 圧電型振動ジャイロの等価回路 (a)等価電気機械回路，(b)等価電気回路

Fig.2 Equivalent circuits of a piezoelectric vibratory gyro.

(a) Electromechanical circuit, (b) Electric circuit.

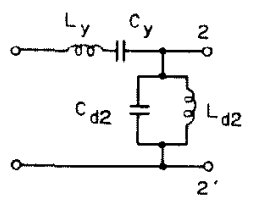

(a)

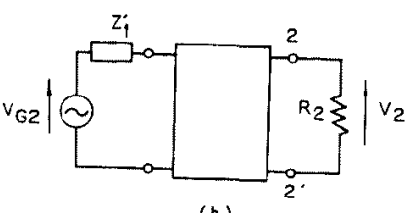

(b)
図 3 検出側等価回路

（a）基本回路，(b)負荷を考慮した回路

Fig.3 Equivalent circuits for the detecting side.

(a) Basic circuit, (b) Circuit including the termination.

と実現される帯域幅 $\Delta$ 及び終端抵抗R2は，それぞれ式(1) のように整理・表示される(8)。

$$
\begin{aligned}
\mathrm{L}_{\mathrm{d} 2} & =\left(\omega_{0 \mathrm{y}^{2}} \mathrm{C}_{\mathrm{d} 2}\right)^{-1} \\
\Delta & =\left(\mathrm{L}_{\mathrm{y}} \mathrm{C}_{\mathrm{d} 2}\right)^{-1 / 2}=\left(\mathrm{C}_{\mathrm{y}} \omega_{0 \mathrm{y}}{ }^{2} / \mathrm{C}_{\mathrm{d} 2}\right)^{-1 / 2} \\
\mathrm{R}_{2} & =0.8 \times\left(\mathrm{L}_{\mathrm{y}} / \mathrm{C}_{\mathrm{d} 2}\right)^{1 / 2} \\
& =0.8 \times\left(\mathrm{L}_{\mathrm{d} 2} / \mathrm{C}_{\mathrm{y}}\right)^{1 / 2}
\end{aligned}
$$

\section{$<3 \cdot 2>$ 設計例}

ここでは，実測された表 1 の $\mathrm{L}_{\mathrm{y}}\left\llcorner\mathrm{C}_{\mathrm{d} 2}\right.$ の值を用いて付加 インダクタンス $\mathrm{L}_{\mathrm{d} 2}$, 带域幅 $\Delta$ を求め, 終端抵抗 $\mathrm{R}_{2}$ の值は 後述のように入出力電圧比特性の平坦性を考虑して算出し た。即ち， $\mathrm{L}_{\mathrm{d} 2}=383.6 \mathrm{mH}, \Delta / 2 \pi=297 \mathrm{~Hz}, \mathrm{R}_{2}=135 \mathrm{k} \Omega$ のように決定された。

\section{4. 入出力電圧比}

図 2 の出力電圧比 $\left|V_{2}\right| /\left|V_{1}\right|$ 及びその位相差 $\theta_{2}$ は，その $[\mathrm{F}]$ 行列の要素A，Bを用いて式(2)及び式(3)の ように導出される。ただし、ここでは漏机出力の影響を考 慮していないので, $V_{\Omega}$ と的をコリオリカによる出力電死 とその位相とすると， $\mathrm{V}_{2}=\mathrm{V}_{\mathrm{\Omega}}, \theta_{2}=\theta_{\Omega}$ となる。 


$$
\begin{aligned}
& \left|V_{Q}\right| /\left|V_{1}\right|=\left\{\left(A_{R}+B_{R} / R\right)^{2}\right)^{2} \\
& \left.+\left(A_{x}+B_{x} / R_{2}\right)^{2}\right\}-1 / 2 \text {, } \\
& \mathrm{A}_{\mathrm{R}}=\mathrm{R}_{\mathrm{x}}\left(1-\mathrm{X}_{\mathrm{y}} \mathrm{X}_{\mathrm{d} 2}\right) / \overline{\mathrm{G}_{\mathrm{x}}}-\mathrm{R}_{\mathrm{y}} \mathrm{X}_{\mathrm{x}} \mathrm{X}_{\mathrm{d} 2} / \overline{\mathrm{G}_{\mathrm{x}}}, \\
& \mathrm{A}_{\mathrm{x}}=\mathrm{R}_{\mathrm{x}} \mathrm{R}_{\mathrm{y}} \mathrm{X}_{\mathrm{d}} / \overline{\mathrm{G}_{\mathrm{x}}}+\mathrm{X}_{\mathrm{x}}\left(1-\mathrm{X}_{\mathrm{y}} \mathrm{X}_{\mathrm{d} 2}\right) / \overline{\mathrm{G}_{\mathrm{x}}}+\overline{\mathrm{G}_{\mathrm{y}}}{ }^{\prime} \mathrm{X}_{\mathrm{d} 2} \text {, } \\
& \mathrm{B}_{\mathrm{R}}=\mathrm{R}_{\mathrm{x}} \mathrm{R}_{\mathrm{y}} / \bar{G}_{\mathrm{x}}^{\prime}-\mathrm{X}_{\mathrm{x}} \mathrm{X}_{\mathrm{y}} / \bar{G}_{\mathrm{x}}{ }^{\prime}+\bar{G}_{\mathrm{y}}{ }^{\prime} \text {, } \\
& \mathrm{B}_{\mathrm{x}}=\mathrm{R}_{\mathrm{x}} \mathrm{X}_{\mathrm{y}} / \overline{\mathrm{G}_{\mathrm{x}}}+\mathrm{R}_{\mathrm{y}} \mathrm{X}_{\mathrm{x}} / \overline{\mathrm{G}_{\mathrm{x}}} \mathrm{X}^{\prime} \\
& \mathrm{X}_{\mathrm{x}}=\omega \mathrm{L}_{\mathrm{x}}-\left(\omega \mathrm{C}_{\mathrm{x}}\right)^{-1} \text {, } \\
& \mathrm{X}_{\mathrm{y}}=\omega \mathrm{L}_{\mathrm{y}}-\left(\omega \mathrm{C}_{\mathrm{y}}\right)^{-1} \text {, } \\
& \mathrm{X}_{\mathrm{d} 2}=\omega \mathrm{C}_{\mathrm{d} 2}-\left(\omega \mathrm{L}_{\mathrm{d} 2}\right)^{-1} \text {, } \\
& \theta_{22}=\tan ^{-1}\left\{-\left(R_{2} A_{x}+B_{x}\right) /\left(R_{2} A_{k}+B_{k i}\right)\right\}
\end{aligned}
$$

図 4 は $\Omega_{0}=100\left({ }^{\circ} / \mathrm{sec}\right)$ とした場合の入出力電圧比 $\left|\mathrm{V}_{\mathrm{a}}\right| /\left|\mathrm{V}_{1}\right|$ <駆動側共振周波数 $\mathrm{f} 0 \mathrm{x}$ の関保等価回路 計算した結果である。同図の(a)はインダクタンス㨀入時の 特性である。また，(b)，(c)は無㧴入時の特性で，負荷抵抗 をそれぞ机 $\mathrm{R}_{2}=\mathrm{R}_{0}=1 /\left(\omega_{0 \mathrm{y}} \mathrm{C}_{\mathrm{d} 2}\right), \mathrm{R}_{2}=10 \mathrm{R}_{0}$ とした場合である。 ここで, $\mathrm{f}_{0 \mathrm{x}}$ は駆動周波数 $\mathrm{f}_{\mathrm{d}}$ に常に一致させて $\mathrm{f}_{0 \mathrm{x}}=\mathrm{f}_{\mathrm{d}}$ として可変させている。また，同図における $\mathrm{f} \mathrm{yy}^{\prime}$ 忏付加イ ンダクタンスがない場合の出力端子開放時の制動容量 $\mathrm{C}_{\mathrm{d} 2}$ の影響をも考慮した検出側の共振周波数で，検出側の容量 比を $\gamma_{\mathrm{y}}\left(=\mathrm{C}_{\mathrm{d} 2} / \mathrm{C}_{\mathrm{y}}\right)$ とすると, $\mathrm{f}_{\mathrm{oy}} \mathrm{y}^{\prime}=\mathrm{f}_{\mathrm{oy}}\left(1+1 / \gamma_{\mathrm{y}}\right)^{1 / 2}$ と与え られる。

これより，インダクタンスを付加すると付加しない場合 より電压比が大きく一定となる周波数範囲がかなり広帯域 に及九でいることが確認された。したがって、この平坦特 性の範囲内で駆動側の共振周波数 $\mathrm{f}$ ox 责, 検出感度の低下 無しに検出側の共振周波数 $\mathrm{f}$ oy 可能となる。また， $\mathrm{f}_{0 \mathrm{x}}$ の值が多少変化しても㶼出感度に は変化がない構成となることも分かる。

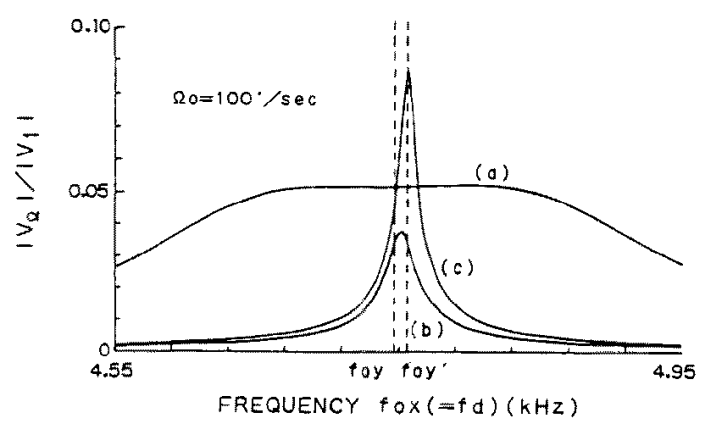

图 4 駆動側共振周波数に対する入出力電圧比特性

Fig.4 Characteristics of $\left|V_{0}\right| /\left|V_{1}\right|-f_{0 x}$.
(a) $\mathrm{Ld}_{2}=383.6 \mathrm{mH}, \mathrm{R}_{2}=135 \mathrm{k} \Omega$,
(b) $\mathrm{R}_{2}=\mathrm{R}_{0}=11.42 \mathrm{k} \Omega$, (c) $\mathrm{R}_{2}=10 \mathrm{R}_{0}$.

一方, 图 5はこのときの入出力間の位相差 $\theta_{\mathrm{R}} と \mathrm{f} \mathrm{f}_{\mathrm{ox}}$ の関 係の計算結果で，インダクタンス $\mathrm{L}_{\mathrm{d} 2}$ を付加した場合には 無付加の場合と比較して使用周波数に扝斿る位相变化が少

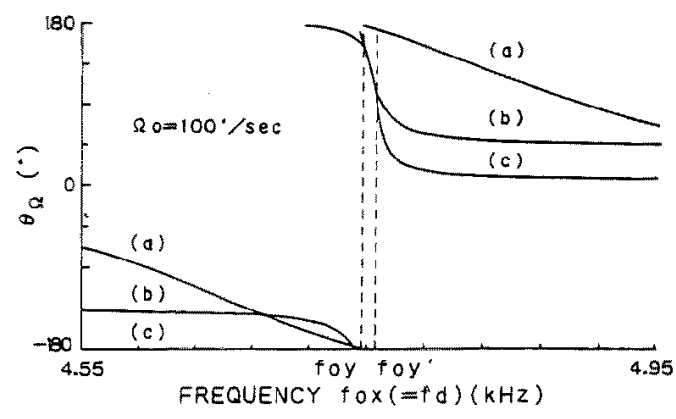

図 5 駆動側共振周波数に対子る入出力間位相差特性

Fig.5 Characteristics of $\theta_{\Omega^{-}}-\mathrm{f}_{0 \mathrm{x}}$.

(a) $\mathrm{L}_{\mathrm{d} z}=383.6 \mathrm{mH}, \mathrm{R}_{2}=135 \mathrm{k} \Omega$,

(b) $R_{2}=R_{0}=11.42 \mathrm{k} \Omega$, (c) $R_{2}=10 R_{0}$.

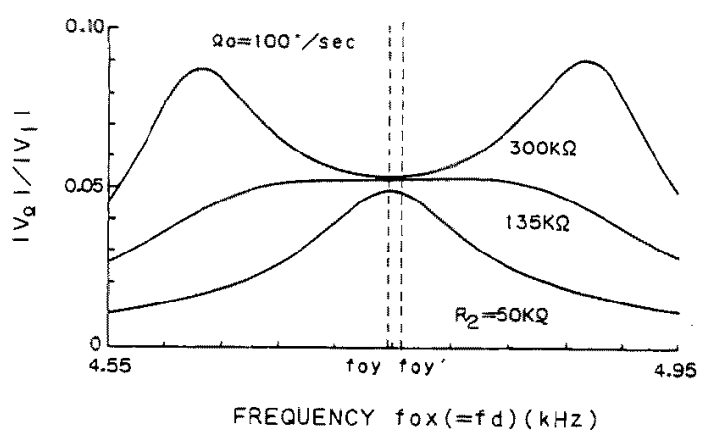

図6 インダクタンス素子付加時の入出力電圧比特性 Fig.6 Characteristics of $\left|\mathrm{V}_{Q}\right| /\left|\mathrm{V}_{1}\right|-\mathrm{f}_{0 \mathrm{x}}$, with inductance element.

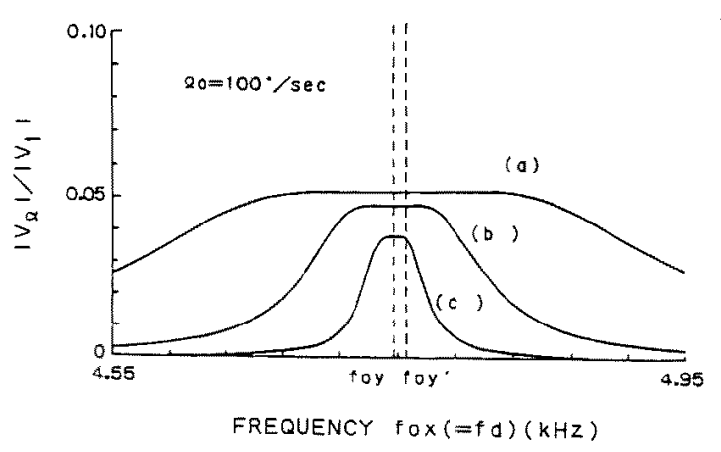

图 7 入出力電压比特性

Fig.7 Characteristics of $\left|V_{\Omega}\right| /\left|V_{1}\right|-f_{0 x}$. (a) $\mathrm{L}_{\mathrm{d} 2}=383.6 \mathrm{mH}=\mathrm{Ld}_{\mathrm{d} 0}, \mathrm{C}_{\mathrm{d} 2}=2930 \mathrm{pF}=\mathrm{C}_{\mathrm{d} 0}, \mathrm{R}_{2}=135 \mathrm{k} \Omega$,

(b) $\mathrm{L}_{\mathrm{d} 2}=\mathrm{L}_{\mathrm{d} 0} \times 0.1, \mathrm{C}_{\mathrm{d} 2}=\mathrm{C}_{\mathrm{d} 0} \times 10, \mathrm{R}_{2}=43 \mathrm{k} \Omega$,

(c) $\mathrm{L}_{\mathrm{d} 2}=\mathrm{L}_{\mathrm{d} 0} \times 0.01, \mathrm{C}_{\mathrm{d} 2}=\mathrm{C}_{\mathrm{d} 0} \times 100, \mathrm{R}_{2}=14 \mathrm{k} \Omega$.

なくなる。検出出力を同期検波して使用する観点からする と，位相変化の少ないことは望ましいと言える。また，四 6 は $\mathrm{L}_{\mathrm{d} 2}=383.6 \mathrm{mH}$ としてR之の值を変えた場合の特性変 化を示したもので，整合抵抗值 $R_{2}=135 \mathrm{k} \Omega$ とき実効 $\mathrm{Q}$ 值 の低下により，图示のような良好な特性が実現される。こ 
のとき，負荷抵抗 $R_{2}$ の值をさらに大きくして検出端子開放 状態 $\left(\mathrm{R}_{2}=\infty\right)$ に接近させるに従い愔相変化はさらに小さ くなり殆ど変化しなくなるので，周波数応答特性に扔行る 位相遅れのきわめて小さい構成の実現も可能となる。

さらに，図 7 には $\mathrm{L}_{\mathrm{d} 2} \mathrm{C}_{\mathrm{d} 2}=\omega \mathrm{oy}^{2}=$ - 定の条件を保って $\mathrm{L}_{\mathrm{d} 2}$ の值を変化させた場合の電圧比 $\left|\mathrm{V}_{0}\right| /\left|\mathrm{V}_{1}\right|$ と周波 数 $\mathrm{f} 0 \mathrm{x}$ の関係を示した。 $\mathrm{L} 2$ の值の減少と共に平坦部の電圧 比は小さくなり，帯域幅 $\Delta$ の狭い特性となる。図8はこの 場合の位相变化を示したもので, $\mathrm{L}_{\mathrm{d} 2}$ の值の減少と共に位相 変化が大きくなる。式(1)による $\mathrm{Ld}_{\mathrm{d} 2}$ の設計值が奏現困難と 思われる場合には、これらの結果を参考にして L $\mathrm{L}_{\mathrm{d} 2}$ の值を 寒現可能な值にすることもできる。

なお，同時に振動ジャイロの入力端子にもインダクタン ス $\mathrm{L}_{\mathrm{d} 1}$ を $\mathrm{C}_{\mathrm{d} 1}$ と並列に付加した場合についても考察してい るが(2)(4), 電圧比 $\left|\mathrm{V}_{0}\right| /\left|\mathrm{V}_{1}\right|$ は $\mathrm{L}_{\mathrm{d} 1}$ 及び入力抵抗 $\mathrm{R}_{1}$ の 存在には無関係の表現となり，険出側にだけに付加した本 考察結果と等しいので,ここでは省略した。

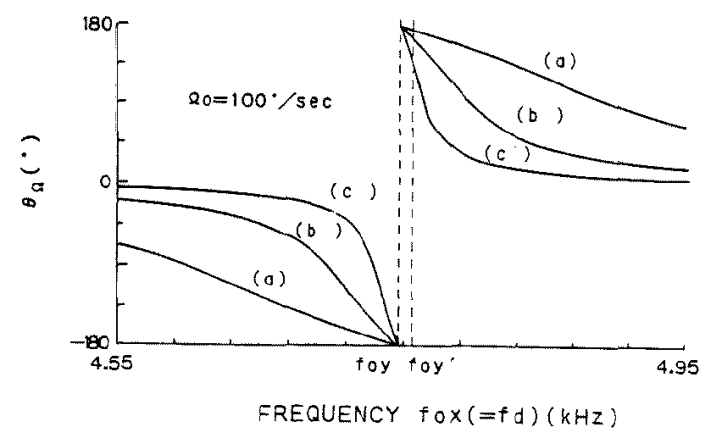

図 8 入出力間位相差特性

Fig. 8 Characteristics of $\theta_{\Omega}$ - fox.

(a) $\mathrm{L}_{\mathrm{d} 2}=383.6 \mathrm{mH}=\mathrm{L}_{\mathrm{d} 0}, \mathrm{C}_{\mathrm{d} 2}=2930 \mathrm{pF}=\mathrm{C}_{\mathrm{d} 0}, \mathrm{R}_{2}=135 \mathrm{k} \Omega$,

(b) $\mathrm{L}_{\mathrm{d} 2}=\mathrm{L}_{\mathrm{d} 0} \times 0.1, \mathrm{C}_{\mathrm{d} 2}=\mathrm{C}_{\mathrm{d} 0} \times 10, \mathrm{R}_{2}=43 \mathrm{k} \Omega$,

(c) $\mathrm{L}_{\mathrm{d} 2}=\mathrm{L}_{\mathrm{d} 0} \times 0.01, \mathrm{C}_{\mathrm{d} 2}=\mathrm{C}_{\mathrm{d} 0} \times 100, \mathrm{R}_{2}=14 \mathrm{k} \Omega$.

\section{5. 実験的検討}

インダクタンスを付加した場合の振動ジャイロにおいて は，前式(1)加㽞区動周波数 $\mathrm{f}_{\mathrm{d}}\left(=\mathrm{f}_{0 \mathrm{x}}\right)$ を $\mathrm{f}_{0 \mathrm{y}}(1 \pm \Delta / 4 \pi)$ の䇶囲に設定すれば，感度低下のない構成が可能である。 ここでは，この振動ジャイロの特性とインダタタンスを付 加しない従来の構成の特性とを比較して，提案した本手法 の妥当性を検証する。このため，これらの特性の等価回路 考察及びその実験的榆証を行った。ただし，この等洒回路 シミュレーションに用いた回路定数は $\mathrm{Q}_{\mathrm{x}}=3,039$, $\mathrm{Q}_{\mathrm{y}}=1,357$ であり, $\mathrm{R}_{\mathrm{i}}$ 以外の他の諸定数は前表 1 とわずか 値が異なるだけなので(5)，ここでは省略した。

\section{$<5 \cdot 1>$ 角速度特性}

まず，図 9 は $\Omega_{0}=90(\% / \mathrm{sec})$ とした場合の入出力電圧比 $\left|V_{0}\right| /\left|V_{1}\right|$ と駆動側共振周波数 $\mathrm{f} 0 \mathrm{x}$ の関係を計算した

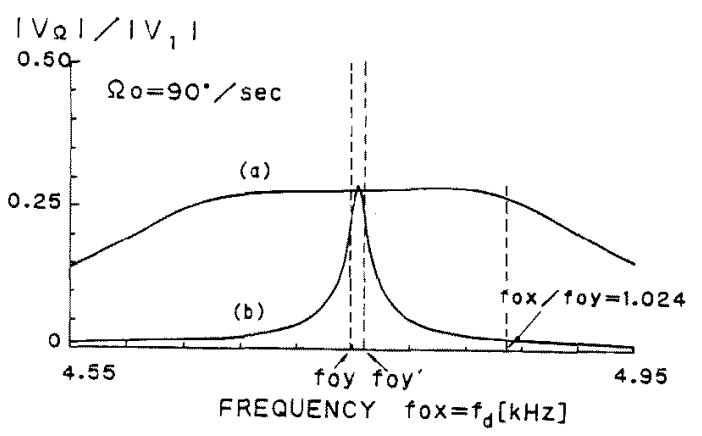

図 9 入出力電王比特性

(a)インダクタンス素子付加時（b)インダクタンス素子無付加時

Fig.9 Characteristics of $\left|\mathrm{V}_{\Omega}\right| /\left|\mathrm{V}_{1}\right|-\Omega_{0}$. (a)With inductance element. $\mathrm{Ld}_{2}=399.5 \mathrm{mH}, \mathrm{R}_{2}=143 \mathrm{k} \Omega$, (b) Without inductance element. $R_{2}=R_{0}=11.9 \mathrm{k} \Omega$.

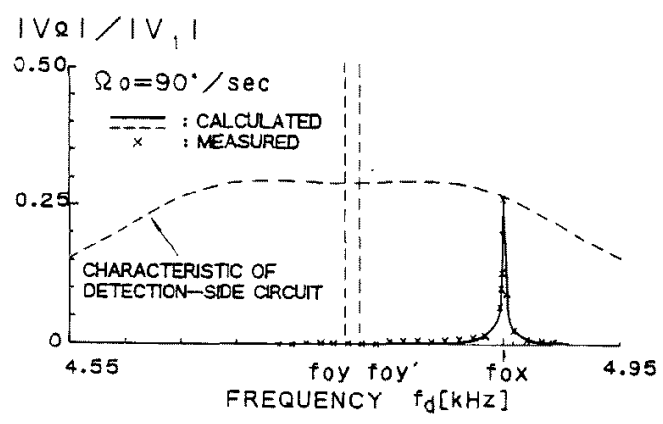

(a)

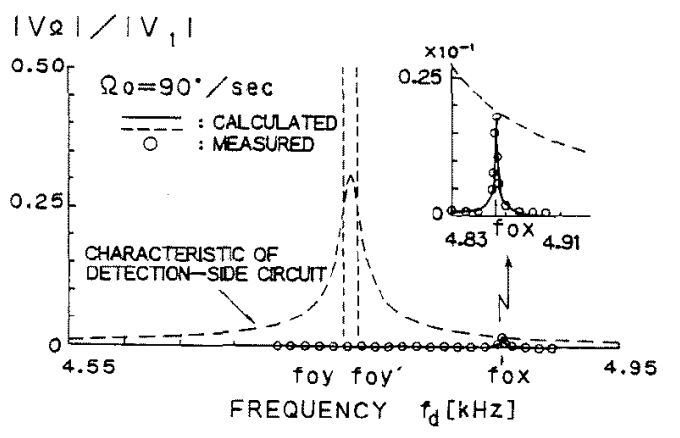

(b)

図 10 入出力電圧比の実験結果

(a)インダクタンス素子付加時, (b)インダタタンス菜子無付加時

Fig.10 Characteristics of $\left|\mathrm{V}_{\Omega}\right| /\left|\mathrm{V}_{1}\right|-\Omega_{0}$.

(a) With inductance element, (b) Without inductance element.

結果である。同図の特性(a)はインダクタンスを付加した場 合で, 特性(b)の無付加の場合と比較して前同様電圧比が大 きく一定の範讲方图示の上うに広くなる。一方, 図 10 は $\mathrm{f} \mathrm{ox}_{0 \mathrm{x}} / \mathrm{f} \mathrm{oy}_{0 \mathrm{y}}=1.024$ と設定した場合の駆動周波数 $\mathrm{f} \mathrm{d}$ に対する 電压比 $\left|\mathrm{V}_{\Omega}\right| /\left|\mathrm{V}_{1}\right|$ の関倸の等価回路シミュレーション 結果及び実験結果である。同図(a)，(b)はそれぞれインダク タンス付加時, 無付加時の特性で, シミュレーション結果 と実験值はよく一致詨応している。これらの特性の電圧比 
$\left|\mathrm{V}_{\Omega}\right| /\left|\mathrm{V}_{1}\right|$ の最大值は前図 9 上の $\mathrm{f}_{0 \mathrm{x}} / \mathrm{f}_{\mathrm{oy}}=1.024 \sigma$ 条件における電圧比に相当する。

さらに，图11は $\Omega_{0}$ に対する同期検波出力 $V_{\Omega} /\left|V_{1}\right| O$ 関倸で，害験值には多少ばらつきが見られるが回路シミュ レーション結果ともほぼ一致寸る直線特性となっている。 これより，インダクタンス付加時の特性は無付加時の特性 より電圧比がかなり大きく高感度となることが確認された。

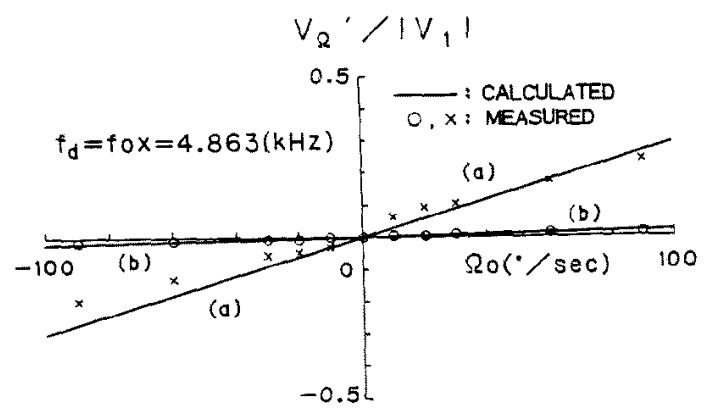

図 11 入出力電圧比の角速度特性

(a)インダクタンス素子付加時，(b)インダクタンス素子無付加時

Fig. 11 Characteristics of $V_{\Omega} /\left|V_{1}\right|-\Omega_{0}$.

(a) With inductance element, (b) Without inductance element.

$\langle 5 \cdot 2\rangle$ 漏れ出力

ここで， $\Omega_{0}=0$ の角速度が印加されない場合の出力電压，

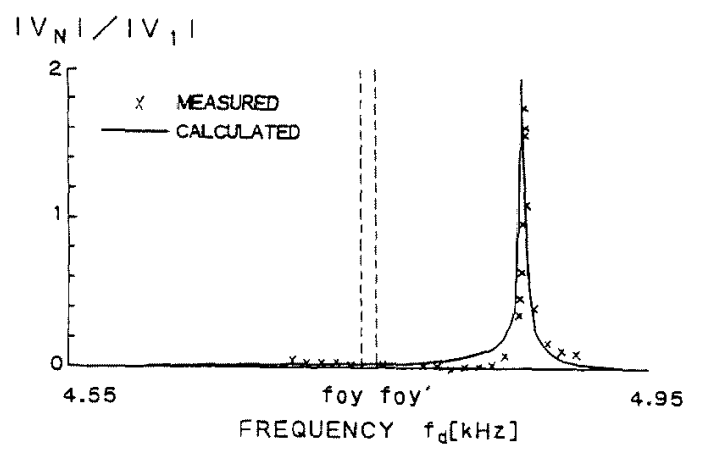

(a)

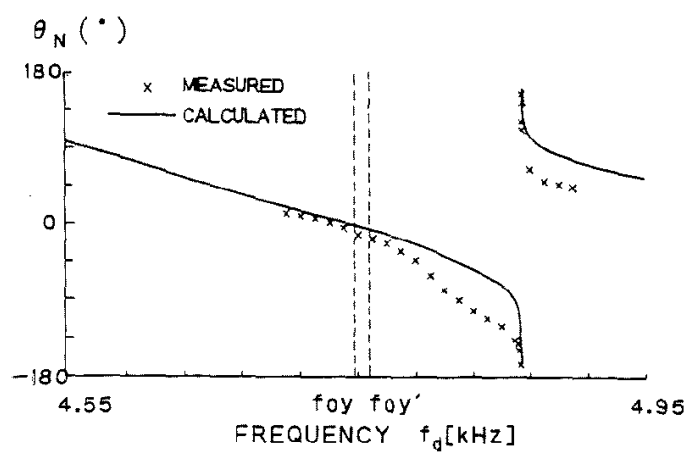

(b)

図 12 インダクタンス素子付加時の漏九出力特性

(a) $\left|V_{N}\right| /\left|V_{1}\right|-f_{d}$ 特性, (b) $\theta \mathrm{N}-\mathrm{f}_{\mathrm{d}}$ 特性

Fig.12 Leakage output in the vibratory gyro with inductance element. (a) Characteristics of $\left|V_{N}\right| /\left|V_{1}\right|-f_{d}$.

(b) Characteristics of $\theta \mathrm{N}-\mathrm{f}_{\mathrm{d}}$.

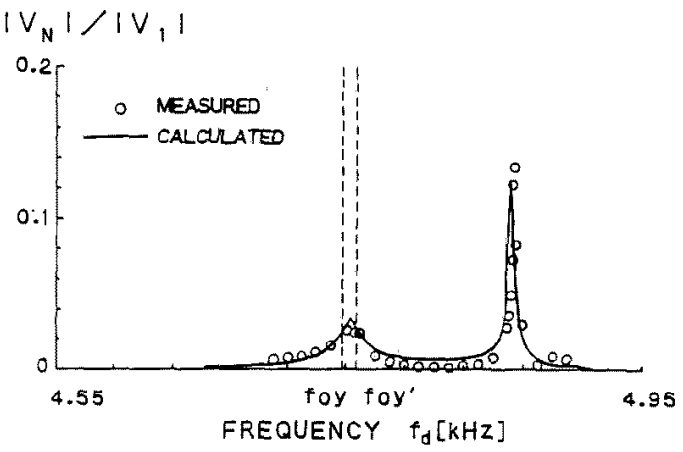

(a)

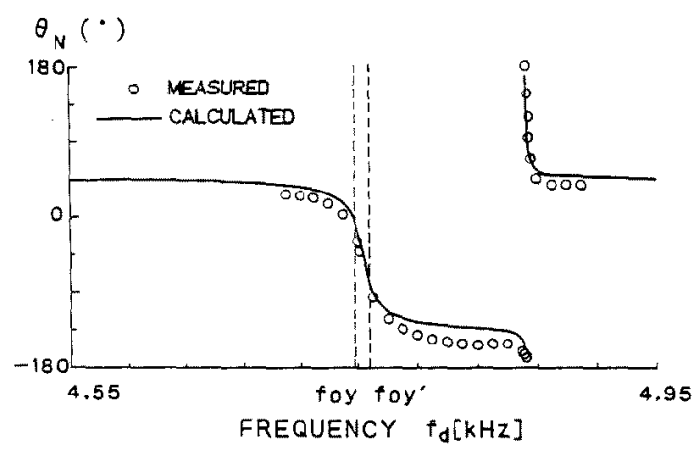

(b)

図 13 インダクタンス素子無付加時の漏孔出力特性

(a) $\left|V_{N}\right| /\left|V_{1}\right|-f_{d}$ 特性, (b) $\theta N_{N}-f_{d}$ 特性

Fig.13 Leakage output in the vibratory gyro without inductance element. (a) Characteristics of $\left|V_{N}\right| /\left|V_{l}\right|-f_{d}$.

(b) Characteristics of $\theta_{N}-f_{d}$.

即ら漏れ出力について考察して見た。図 12 はインダクタン 又付加時の漏え出力 $\mathrm{V}_{\mathrm{N}}$ と駆動周波数 $\mathrm{f}_{\mathrm{d}}$ の関係で，同図(a) はその振幅 $\left|V_{N}\right| /\left|V_{1}\right|$ であり, 同図(b)はその位相 $\theta_{N}$ を表す。図示のように回路シミュレーション結果と実測值 はほぼ一致対応することが分かった。一方，図 13 はインダ クタンス無付加時の漏れ出力 $\mathrm{V}_{\mathrm{N}}$ 上駆動周波数 $\mathrm{f} d$ の関係で ある。この場合も前同様, 計算値と実測值は良く一致対応 している。な扰これらの図の特性シミュレーションには 既に提案されている漏九出力による影響の考慮された等価 回路在利用した(7)。この場合、漏九出力の原因として圧電 セラミックスの接着ずれや電極の非対称性に起因する力倸 数の不要成分の存在を考亚し，その值として $\Delta \mathrm{A}_{2 \mathrm{x}}=-\mathbf{4 . 0 5}$ $\times 10^{-3}(\mathrm{gr} . / \mathrm{H})^{1 / 2}, \Delta \mathrm{A}_{1 \mathrm{y}}=5.75 \times 10^{-3}(\mathrm{gr} . / \mathrm{H})^{1 / 2}$ なる実測值を 採用した。これらの不要力係数成分についての詳細は文献 に譲るが， $\Delta A_{2 x}, \Delta A_{1 y}$ は駆動側の振動が検出側に溻れる 成分，駆動側で検出モードを励振してしまう成分にそれぞ れ相当する。

したがって，回路シミュレーション結果と実測值がほぼ 一致寸るという結果から，本試料では力係数の不要成分 $\Delta \mathrm{A}_{2 \mathrm{x}}, \Delta \mathrm{A}_{1 \mathrm{y}}$ に起因する漏れ出力が支配的となっているこ とが分かった。さらに，インダタタンス付加の場合には無 
付加の場合より漏れ出力が大きくなっていることも分かっ た。何れの場合も漏れ出力は大きく観測されているが, こ れは漏れ出力の低減化の調整は一切実施していないためで, 実際の使用に当たっては各種の低减化の工夫(7)が実施され ることは言うまでもない。

\section{6.あとがき}

圧電型振動ジャイロの駆動側及び検出側の共振周波数を 離調した状態で高感度化を図る一方法として, 検出側端子 に並列にインダクタンスを付加させる簡便な手法を提案し, 実験的にもその妥当性が検証された。得られた結果を要約 すると，

（1）インダクタンスを付加すると，設計した広い带域幅に おいて入出力電圧比が大きく一定值となり，位相変化 の少ない特性が実現できること，

（2）この検出側広带域特性により，共振周波数のばらつき による感度変化が押さえられるという製造上の大きな メリットが生まれること，

（3） $\mathrm{L}_{\mathrm{d} 2} \mathrm{C}_{\mathrm{d} 2}=\omega 0_{\mathrm{y}}{ }^{-2}=$ 一定の条件のもとで，付加インダク タンス值の可変設定が可能であること,

（4）インダクタンス付加時はコリオリカによる出力成分だ けでなく，漏れ出力成分も大きくなるので，その低減 化により両出力成分の比の大きな構成が実現できるこ と,

などが明らかになった。

本研究では，付加インダクタンスとしてコイルを使用し たが，さらに小型化を図るにはオペアンプを利用したイン ダクタンス回路を利用する方法も考えられる。これについ ては，改めて報告したい。

本研究を実施するに当たり御討論頂いた近野正・山形大 学名誉教授並びに富川義朗・同大教授に深謝申し上げます。 なお, 本研究には昭和 63 年度文部省科学研究費補助金 (一 般(C), No.63550284) 及び平成 11 年度同補助金（基盤研 究(C), No.11650057）の援助を受けたことを付記する。

(平成 11 年 08 月 30 日受付, 平成 11 年 11 月 10 日再受付)

\section{文 献}

（1）日刊工業新聞社：“特集 21 世紀に向けての振動ジャイ ロスコープセンサ”，超音波テクノ，Vol.6, No.9, pp.15-53 (1994-09).

（2）菅原, 富川: “圧電形振動ジャイロの等価回路考察”, 日本音響学会, 講論集 (II ), No.2-4-16, pp.833-834 (1988-10).

（3）菅原, 富川, 近野: “圧電形振動ジャイロの入出力イン ピーダンスについて”, 日本音響学会, 講論集(II), No.1-4-7, pp.665-666 (1989-03).

（4）菅原, 工藤：“インダクタンスを挿入した圧電形振動ジ
ヤイロの等価回路解析”, 石巻専修大学研究紀要, No.10, pp.49-59 (1999-02).

（5）菅原，近野，富川：“圧電形振動ジャイロの検出側広带, 域化に関する実験的検討”, 日本音響学会, 講論集(II), No.1-4-7, pp.841-842 (1989-10).

（6）近野，菅原，尾山，中村：“圧電形振動ジャイロ”, 信 学論(A), Vol.J68-A, No.6, pp.602-603 (1985-06).

（7）菅原, 近野, 工藤, 吉田：“横振動音片を用いた圧電形 振動ジャイロスコープの漏れ出力の等価回路考察”, 信 学論(A), Vol.J76-A, No.3, pp.263-272 (1993-03).

（8）近野 正：“メカニカルフィルタ”, 共立出版, p.40 (1954-08).

菅原 澄夫（正員）昭和 22 年 8 月 27 日生。 47 年 3 月

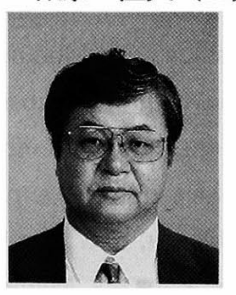
山形大学大学院修士課程修了。同年 4 月 同大学工学部助手, 63 年同助教授, 平成 元年 4 月石巻専修大学理工学部助教授, 平成 9 年同教授, 現在に至る。工学博士。 超音波エレクトロニクス, 特に振動ジャ イロスコープに関する研究に従事。

電子通信学会学術奨励賞。電子情報通信学会, 日本音響学 会会員。

工藤 寸ばる（非会員）昭和 35 年 3 月 9 日生。 59 年

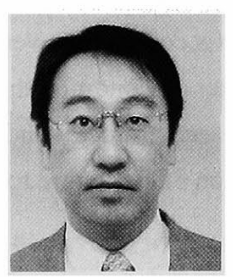
3 月東北大学大学院修士課程修了。同年 4 月横河電機(株)入社, 62 年 12 月アン デス電気(株)入社, 平成元年 4 月石巻専 修大学理工学部助手, 平成 8 年同講師, 現在に至る。博士(工学)。超音波エレク トロニクス，特に振動ジャイロスコープ に関する研究に従事。電子情報通信学会, 日本音響学会会 員。 